\title{
The Link Between Sustainability Reporting and the Core Characteristics of Sustainable Human Resource Management
}

Banu Esra Aslanertik* https://orcid.org/0000-0003-0891-4803

Murat Çolak ${ }^{* \star+}$ https://orcid.org/0000-0002-6135-1694

*Dokuz Eylul University, Izmir, Turkey. Email: esra.aslanertik@deu.edu.tr

**Visiting Professor, AGH University of Science and Technology, Krakow, Poland. Email: colak@muratcolak.com

Abstract

Keywords

Background. The concept of sustainable human resource management is becoming a core subject of sustainability reports. Current discussions in the literature focus on how to integrate human resource management (HRM) with sustainability issues and emphasise the concept of "sustainable human resource management" rather than "sustainability and human resource management." This focus requires a more comprehensive company perspective through the lens of company goals, people, processes and the strategic orientation dimensions of an HRM-sustainability relationship. Within this perspective, new approaches are needed to concentrate on sustainable HRM issues.

Research aims. The aim of this study is to analyse the contents of the sustainability reports in terms of sustainable HR characteristics and HR orientation dimensions. The content analysis design is based on an integrated approach of the classification of sustainable HR characteristics through HR orientation dimensions. The sustainability reports of seven financial institutions from the Borsa Istanbul Sustainability Index (BIST) are analysed for the year 2019 in order to determine to which degree sustainable $H R$ is actively involved in the sustainability reports.

Methodology. In this study, an in-depth content analysis is performed on corporate sustainability reports of selected companies in order to form the link between HR orientation and sustainability. This content analysis stands on the integration of two different approaches drawn from the literature (Ehnert, 2014; Ulrich, 1997).

Findings. The results revealed that there are significant differences between the people-oriented scores and process-oriented scores in private banks, while the scores are more balanced in public banks. Additionally, findings support the shift in the public sector from the traditional bureaucratic model to a new management approach that transfers private sector management techniques to the public sector.

human resource management, sustainability, sustainable human resource characteristics

\section{Introduction}

Since personnel management is business- and process-oriented and ignores the human factor, the concept of personnel management has been replaced by the understanding of human resource management (HRM). Human resource management deals with the management of all processes, from the recruitment of human resources to their dismissal, with the human as the key element in achieving goals (human resource training includes development, motivation, performance, career management, and specialisation in the field). Therefore, the presence and importance of human resources are emphasised at the centre of all applications covered by human resource management. However, it can be said that the main purpose of human resource management is to achieve organisational goals through the integration of individual and organisational goals and ultimately to profit. Digitalisation and the accompanying changes in the field of technology, emerging new business lines and new markets, and the ever-increasing competitive environment have made it obligatory for organisations to think, make decisions, and plan strategically or, in other words, to pursue strategic management of their human resources. Strategic management of human resources requires organisations to make strategic plans in line with their mission, vision, and goals. The focus in strategic human resource management is to take action together with employees who can make a difference in terms of quality and quantity and achieve the goals of the organisation. It requires taking action as a whole in line with the mission, vision, and goals. As in human resource management, strategic human resource management is also human-based. However, it should not be ignored that human resources are considered strategic resources in strategic human resource management. 
Although human resources and strategic human resource management see human resources as key factors in the success of organisations, the main underlying purpose is financial. However, human resources are much more important and valuable in an organization beyond financial concerns. The process has moved towards a dynamic management approach that focuses on the continuous development of human resources based on the idea of securing today and taking firm steps towards planning the future. This management approach has taken its place in the literature as "sustainable human resource management."

\section{Theoretical And Conceptual Background}

The introduction of sustainable human resource management to the agenda was realised together with the definition of sustainable development in a report published by the Brundtland Commission in 1987. In the report, "sustainable development" was explained as the development that meets today's needs without compromising the ability of future generations to meet their own needs (WCED, 1987, p. 43). The report aimed to develop an agenda for global change and a common future for humanity. This report is particularly important as it deals with the question of how to advance social and economic development without jeopardising natural living conditions for the majority of humanity. It also drew attention to the fact that sustainability is put aside in times of crisis and that existing decision makers in organisations consume resources quickly. Thus, the report argued that crises or resource scarcity are not guarantees of sustainable business behaviour. For this reason, it would not be wrong to say that, through its emphasis on concepts such as sustainability and sustainable development, the Brundtland report was effective in popularising sustainable human resource management (Ehnert \& Harry, 2012: 222; Sneddon et al., 2006).

There are various definitions of sustainable human resource management in the literature. Sustainable human resource management is the management of human resources to meet the optimum needs of the current business and the community without compromising the ability to meet the needs of the future (Mariappanadar, 2003: 910; Wagner, 2013, p. 443). It is defined as ensuring corporate sustainability by developing human resources policies, strategies, and practices that support economic, social, and environmental dimensions (Freitas et al., 2011: 226). This definition addresses sustainable human resource management from a holistic perspective.

Sustainable human resource management is defined as the use of human resources tools to help establish the sustainability strategy in the business and create a human resources system that will contribute to the business's sustainable performance. It also helps ensure the long-term health and sustainability of both internal and external stakeholders of the business and supports environmentally friendly practices with policies that reflect equality, development, and well-being (Cohen et al., 2012, p. 3; Macke \& Genari, 2019). In addition, sustainable human resource management is clarified as controlling unwanted side effects and negative feedback from the adoption of human resource management strategies and practices that ensure the achievement of financial, social, and ecological goals with long-term impact inside and outside the business (Ehnert et al., 2016, p. 90; Jabbour \& Santos, 2008, p. 2145). Therefore, it is important in terms of sustainable human resource management that human resource management strategies are presented clearly and internalised by internal and external customers.

Based on these explanations, it can be said that human resource management refers to the social and humanitarian results that contribute to the long-term continuation of organisations or, in other words, to a sustainable organization. The term was also used to refer to human resource management activities that promote positive environmental outcomes, green human resource management, and positive social/human outcomes rather than mediating factors between financial results and strategy. In short, sustainable human resource management recognises the human and social perspectives of organisations and the impact of human resources on the success and survival of organisations (Kramar, 2014, p. 1075). Its objectives include balancing the uncertainty and duality of productivity and sustainability over a long period; protecting, developing, and increasing the personnel and social resource base of an organization through mutual exchange relations; and evaluating and examining the negative effects of human resources activities on human resources (Ehnert, 2006, p. 14).

A framework was presented to classify and comprehensively understand the potential role that human resources could play in sustainability. The roots of this framework are based on the process/human and internal/external dimensions commonly used in human resource management and sustainability literature. Accordingly, process orientation covers the technical role performed by the human resources function, but human orientation covers the social role performed by the human resources function. According to the framework presented, the function of human resources focuses on the development of sustainable human resource management systems, sustainable business organisations, sustainable corporate ecosystems, and sustainable local/ global communities. The aim here is to present a typology to map the relationships between different human resource roles as well as the different roles that human resources can play in promoting sustainability (De Stefano et al., 2018). 
Emerging as an alternative approach in human resource management, sustainable human resource management represents a new approach to managing human resources by setting broader goals. The sustainable human resources literature shows that human resource management affects more than organisational economic performance. It also affects organisational results such as return on investment, market share, and profit. These have an impact not only on organisational economic results, such as operational activities, but also on social and ecological results, and these results are considered an integral part of sustainable human resource management (Kramar, 2014, pp. 1084-85; Westerman et al., 2020; Chams \& García-Blandón, 2019; Tooranloo et al., 2017, p. 1263).

Sincerity towards employees and creating opportunities for them to develop, creating a good working environment and conditions, and paying attention to their physical/psychosocial well-being are the topics considered and attended to under this management approach (Wikhamn, 2019, p. 103).

"Long-term orientation," which means integrating the future with the present, "care of employees," which refers to all efforts to protect a healthy and productive workforce, and "care of the environment," which is known as focusing on environmental problems and managing according to environmental criteria are among the features of sustainable human resource management. Making a profit with financial indicators is a natural goal of businesses. Taking into account this goal, profitability is another feature that should not be ignored as a dimension of sustainable human resource management. However, employee participation and social dialogue and employee development are among the other important features. Employee development includes activities for training and developing employees. Employee development is also very valuable because it reflects concern for both today and the future and sends a message to employees about wanting to keep them for the long term. Issues such as necessary resources, external partnerships, working hours, leaves, remote working, holidays, awards, flexible arrangements related to retirement, compliance beyond labour regulations, information sharing, trust, respect, open and proactive communication-oriented employee cooperation, and fairness and equality (meaning that responsibilities and rights are the same for everyone in an organisation) are evaluated within the scope of the basic features of sustainable human resource management (Stankevičiūtè \& Savanevičienè, 2018).

When all the features that have been briefly explained above are considered together, it can be seen that they are all interrelated. Therefore, each feature is evaluated within the indispensable characteristics of sustainable human resource management. Along with these features of sustainable human resource management, human resources are accepted as a goal, not a tool to achieve business goals. The focus is on organisational results in the short, medium, and long term, along with human resources as a value. In the end, the aim is to invest in the future by securing and improving the current situation. Therefore, the most important aspect that should not be overlooked in sustainable human resource management is a human resource, which is considered a value. Therefore, the focus should not be on the consumption of human resources but on renewing and improving them.

With these explanations, it is seen that sustainable human resource management has emphasised the win-win approach to changing and transforming the world and has become an important issue today, as it incorporates both employers and employees in a wide perspective. The change and transformation experienced over time have made human resources even better and more important than in the previous management approach. It should be noted that sustainable human resource management does not reject previous management approaches, including strategic human resource management and human resource management. On the contrary, each approach is complementary to the previous approach. It is thought that this situation arises from the dynamic structure of the internal and external environment.

\section{METHOD}

\section{Aim of the Research}

The aim of this study is to perform a link between sustainability and HR orientation dimensions using content analysis on sustainability reports. The content analysis is designed based on an integrated approach of sustainable HR characteristics classification through HR orientation dimensions. The research model designed for the content analysis is explained in the next section.

\section{Research Model}

Ehnert (2014) has defined Sustainable HRM as "the pattern of planned or emerging human resource strategies and practices intended to enable organisational goal achievement while simultaneously reproducing the HR base (inside and outside the organisation) over a long-lasting calendar time and controlling for self-induced side and feedback effects of HR systems on the HR base and thus on the company itself." This definition offers a more comprehensive company perspective through company 
goals, people, processes, and strategic orientation dimensions of HRM-sustainability relationship. Within this perspective, a new approach is needed to concentrate on sustainable HRM issues.

In this study, an in-depth content analysis is performed on 1,515 pages of corporate sustainability reports from selected companies in order to form the link between HR orientation and sustainability. This content analysis stands on the integration of two different approaches drawn from the literature. The first approach, developed by Ulrich (1997), determines two HR orientation dimensions:

1. A present or future orientation

2. A people or process orientation

Additionally, Zink (2014) emphasised the need for two different approaches - the economic approach and the integrative approach - for considering the HRM and sustainability relationship. The economic approach mainly refers to the use of HR as a production factor, which is closer to the process-orientated. The integrative approach refers to the better management of people to increase productivity through quality of work life, which is more people-oriented. According to De Stefano et al. (2018), the contrast between people and processes helps reveal a company's orientation of HR activities toward sustainability. Regarding the roles performed by the HR function, a people orientation focuses on the social role while the process orientation refers to the technical role. Table 1 shows the HR activities related to HR orientations (Lam \& Khare, 2010; Malik et al., 2010; Zink, 2014).

Table 1. HR Activities and HR Orientations

\begin{tabular}{ll}
\hline PROCESS ORIENTATION & PEOPLE ORIENTATION \\
\hline Recruitment and staffing & Employee well-being \\
Performance management & Safety \\
Compensation and benefits & Psychological status \\
Talent management and development & Job satisfaction \\
Training and development & Coping with stress \\
Leadership development & Health conditions \\
Communication & Work-life balance \\
\hline
\end{tabular}

Source: Authors' own description, based on research results.

The second approach for the structure of content analysis proposed by Stankevičiūtè and Savanevičienè (2018) includes 11 characteristics of sustainable HRM and their core aspects, which are drawn from the literature listed in the previous section. As mentioned above, the content analysis integrates two approaches. Regarding this, these 11 characteristics are classified into two main groups as process-oriented characteristics and people-oriented characteristics. Then, the sustainability reports of seven financial institutions (banks) from the BIST are analysed for the year 2019 in order to determine at what level sustainable $\mathrm{HR}$ is actively involved in their sustainability reports through 11 characteristics. Also, the orientation of this involvement (people or process) was investigated by using the integrated structure given in Table 2.

Table 2. Integrated Structure for Sustainable HR Characteristics and HR Orientation Dimensions (Classification of Characteristics Based on HR Orientations)

\begin{tabular}{ll}
\hline PROCESS-ORIENTED SUSTAINABLE HR CHARACTERISTICS & PEOPLE-ORIENTED SUSTAINABLE HR CHARACTERISTICS \\
\hline Care of environment & Long-term orientation \\
Profitability & Care of employees (safety and health) \\
Employee development & Employee participation \\
External partnership & Compliance beyond labour regulations \\
Flexibility & Employee cooperation \\
& Fairness and equality \\
\hline
\end{tabular}

Source: Authors' own description, based on research results.

The content analysis can be quantitative or qualitative. In this research, both quantitative and qualitative content analysis is performed, based on interpreting and understanding the HR involvements of sustainability reports by measuring the importance levels of core sustainable HR characteristics with their core aspects. For example, the "care of employees" characteristic 
is analysed by using the patterns of "health \& safety management" and "work-life balance" with their frequencies and/or emphases on these patterns in the reports. According to these frequencies and/or emphases, a scoring system is developed to evaluate the importance levels of the core aspects of sustainable HR characteristics in sustainability reports as given in Table 3 .

Table 3. Scoring System of Core Sustainable HR Characteristics

\begin{tabular}{lll}
\hline SCORES & LEVELS & EXPLANATIONS \\
\hline 0 & Not mentioned & Core aspects are not included \\
1 & Very limited & Core aspects are poorly included \\
2 & Limited & Core aspects are included by some quantitative data only, such as statistics or tables \\
3 & Exhaustive & Core aspects are included as detailed descriptions, graphs, statistics under most of the headings \\
4 & Very exhaustive & $\begin{array}{l}\text { Nearly all different types of core aspects are well reported, explicitly expressed, and very well de- } \\
\text { tailed under different headings }\end{array}$ \\
\hline
\end{tabular}

Source: Authors' own description, based on research results.

In previous research, this kind of scoring system is mainly used to evaluate the sustainability reporting quality of the companies (Daub, 2007; Vormedal \& Ruud, 2009; Aggarwal \& Singh, 2019). Ehnert et al. (2016) used a methodology based on the analysis of core performance indicators of the Global Reporting Initiative (GRI) categories related to "labour" and "human rights" to assess the HRM aspects of sustainability within sustainability reports, but this research is totally quantitative. The research model developed here offers a scoring system based on the interpretation of core aspects of the sustainable HR activities of the companies. Due to its interpretation dimension, the scoring system developed includes a $0-4$ scale to evaluate the level of the emphasis given on the core aspects of sustainable HR. This research differs from other research by scoring the interpretations and trying to determine the level of importance given to sustainable HR activities.

\section{Limitations of the Research}

This research has potential limitations. Initially, the content analysis was limited to the review of sustainability reports published in 2019 by seven financial institutions only, and all of them are public or private banks. Considering that there are various numbers of sustainability reports prepared by the companies for various years, the generalizability of findings may be lower due to the level of information provided in the sustainability reports of these companies in 2019. Because of the magnitude of reports available, it was necessary to limit the number of reports, so only the year 2019, as the most recent year, was selected. In order to make an in-depth analysis and to provide more detail about the findings, the sample size is restricted to seven banks. Future work can be extended to a multiyear analysis so that the changes in HR orientation dimensions and in sustainable HR characteristics of companies can be investigated over a span of years. This type of analysis will enable us to trace the improvement of the HR vision of banks over time.

In addition, the content analysis may involve some subjective interpretations due to researcher-based qualitative analysis, which can affect the generalizability and/or validity of the findings. In this study, to decrease the level of subjectivity, the sustainability reports were analysed and scored by both researchers independently. Although there were no significant differences in the perceptions of the researchers, the following process was established to come to a common conclusion should differences in scoring emerge:

- First, each researcher explained their own findings on the related characteristic in terms of phrases, sentences, graphs, tables, statistics given in the reports.

- Second, the findings were compared to determine if there are any skipped data and/or a different perception of the level of the data in the reports.

- Last, the results of the first two steps were discussed to reach a common conclusion about the items.

\section{FINDINGS}

The analysis of the sustainability reports consists of the following steps:

1. Reading all the sustainability reports of seven banks to have a general view of their HR involvements and sustainable HR activities.

2. Observing the core characteristics of sustainable HR and documenting the core aspects reported in terms of headings, graphs, tables, sentences, and paragraphs. 
3. Scoring the frequencies and/or emphases given on each type of core aspect according to the documentation made in the second step.

4. Classifying scores as achieved from process-oriented sustainable HR characteristics and as scores achieved from peopleoriented sustainable HR characteristics.

The content analysis has been done by researchers from a qualitative and quantitative perspective by analysing both the emphases given on each separate core aspect and its frequency under each different heading in the reports. The presence of each core characteristic is checked in the sustainability reports. Then, these characteristics are further assessed in terms of emphasis, comprehensiveness, and frequency. Table 4 demonstrates as an example how the sustainable HR core characteristics with their core aspects were documented and scored for each bank.

Table 4. A Demonstration of Content Analysis and Scoring

\begin{tabular}{|c|c|c|c|}
\hline Characteristics of Sustainable HR & The Core Aspects & YAPI VE KREDİ & SCORES \\
\hline Long-term orientation & $\begin{array}{l}\text { Identification of the availability of human } \\
\text { resources in the future; identification of the } \\
\text { needs of the future employees; elimination of } \\
\text { the "hire and fire" approach }\end{array}$ & $\begin{array}{l}\text { Competent workers with future skills, carrier } \\
\text { orientation and planning (Very Exhaustive) }\end{array}$ & 4 \\
\hline Care of employees & $\begin{array}{l}\text { Health and safety management; work-life } \\
\text { balance }\end{array}$ & $\begin{array}{l}\text { Work-life balance, Health and Safety } \\
\text { Management policies, family violence support } \\
\text { mechanisms (Very Exhaustive) }\end{array}$ & 4 \\
\hline Care of environment & $\begin{array}{l}\text { Evaluating the employee performance } \\
\text { according to environment-related criteria; } \\
\text { fostering "eco-career"; employee rewarding } \\
\text { according to environment-related criteria }\end{array}$ & Not mentioned & 0 \\
\hline Profitability & Share programs & $\begin{array}{l}\text { Wage Payment Systems, technical and } \\
\text { developmental performance evaluation, } \\
\text { bonuses (Exhaustive) }\end{array}$ & 3 \\
\hline Employee participation and social dialogue & Different types and forms of participation & $\begin{array}{l}\text { Employee participation, strong social } \\
\text { communication, club activities, worker } \\
\text { voluntariness activities (Very Exhaustive) }\end{array}$ & 4 \\
\hline Employee development & $\begin{array}{l}\text { Job rotation; different training forms and } \\
\text { methods; the transfer of experience; focus on } \\
\text { future skills and employability }\end{array}$ & $\begin{array}{l}\text { Future skills and employability, job rotation, } \\
\text { apprenticeship and job training, talent } \\
\text { management policies and programs, } \\
\text { education academy, worker satisfaction } \\
\text { (Very Exhaustive) }\end{array}$ & 4 \\
\hline External partnership & $\begin{array}{l}\text { Cooperation with education system; } \\
\text { partnership with all external stakeholders }\end{array}$ & $\begin{array}{l}\text { Partnership and strong communication } \\
\text { with universities, apprenticeship programs, } \\
\text { partnership with all external stakeholders } \\
\text { (Very Exhaustive) }\end{array}$ & 4 \\
\hline Flexibility & Flexible working arrangements; job rotation & Flexibility and job rotation (Limited) & 2 \\
\hline Compliance beyond labour regulations & $\begin{array}{l}\text { Involves employee representatives in many } \\
\text { decision-making processes beyond those } \\
\text { for which worker participation is a statutory } \\
\text { requirement; financial and nonfinancial } \\
\text { support }\end{array}$ & $\begin{array}{l}\text { Participatory management, integrating the } \\
\text { personnel in decision-making processes } \\
\text { through a Bank-Labour Union Common } \\
\text { Board Mechanism(Exhaustive) }\end{array}$ & 3 \\
\hline Employee cooperation & $\begin{array}{l}\text { Teamwork; good relationships of managers } \\
\text { and employees }\end{array}$ & $\begin{array}{l}\text { Strong internal communication, consultancy } \\
\text { mechanism, HR Support Call Centre, Digital } \\
\text { Internal Communications Platforms (Very } \\
\text { Exhaustive) }\end{array}$ & 4 \\
\hline Fairness and equality & $\begin{array}{l}\text { Fostering diversity; respectful relationships; } \\
\text { fairness as regards as remuneration, career }\end{array}$ & $\begin{array}{l}\text { Freedom, respect, fairness, transparency and } \\
\text { trust-based culture, opportunity of equality, } \\
\text { diversity, Female Labour Force Statistics } \\
\text { (Very Frequent) }\end{array}$ & 4 \\
\hline
\end{tabular}

Source: Authors' own description, based on research results. 
Table 5 describes the summary of the total and classified scores achieved from the content analysis.

Table 5. Scores Achieved from Core Characteristics of Sustainable HR

\begin{tabular}{|c|c|c|c|c|c|}
\hline \multirow[b]{2}{*}{ NAME OF THE BANK } & \multirow[b]{2}{*}{ TOTAL SCORES } & \multicolumn{4}{|c|}{ CLASSIFIED SCORES } \\
\hline & & & $\begin{array}{c}\text { PEOPLE-ORIENTED } \\
\text { SCORES }\end{array}$ & & $\begin{array}{c}\text { PROCESS-ORIENTED } \\
\text { SCORES }\end{array}$ \\
\hline YAPI VE KREDI & 36 & 23 & & 13 & \\
\hline HALKBANK & 29 & 17 & & 12 & \\
\hline VAKIFBANK & 25 & 14 & & 11 & \\
\hline AKBANK & 22 & 15 & & 7 & \\
\hline GARANTI BBVA & 20 & 15 & & 5 & \\
\hline iş BANKASI & 19 & 14 & & 5 & \\
\hline ŞEKERBANK & 9 & 4 & & 5 & \\
\hline
\end{tabular}

Source: Authors' own description, based on research results.

Two of the banks are public banks: Halkbank and Vakıfbank. All the others are privately held banks. Results revealed that only one bank (Şekerbank) achieved a very low score (9); it is also the only bank that achieved a higher score from process-oriented characteristics. Table 6 shows the content analysis details of Şekerbank and its scores. In general, the sustainability report of Şekerbank is not very detailed compared to the other banks. The bank with the lowest score and least detailed sustainability report shows a process-oriented HR involvement, and this issue requires special attention from the aspect of adopting a "sustainabilityfocused management" approach. In various studies, it was argued that there is a strong relationship between HRM and corporate sustainable development in terms of the contribution of HRM on corporate sustainability (Ehnert \& Harry, 2012; Cohen et al., 2012; Jackson et al., 2011). As a further argument, sustainability of the HRM system was stated as a "survival strategy" for organisations dependent on high-quality employees (Ehnert, 2009). Thus, the relationship between the limited (exhaustive) sustainability focus and the lowest (highest) score from sustainable HR characteristics will not be an astonishing result.

Table 6. Content Analysis Details of Şekerbank

\begin{tabular}{|c|c|c|c|}
\hline $\begin{array}{l}\text { Characteristics of } \\
\text { Sustainable of HR }\end{array}$ & The Core Aspects & ŞEKERBANK & SCORES \\
\hline Long-term orientation & $\begin{array}{l}\text { Identification of the availability of human resources } \\
\text { in the future; identification of the needs of the future } \\
\text { employees; elimination of the "hire and fire" approach }\end{array}$ & Not mentioned & 0 \\
\hline Care of employees & Health and safety management; work-life balance & Occupational Health and Safety (Very Limited) & 1 \\
\hline Care of environment & $\begin{array}{l}\text { Evaluating the employee performance according to envi- } \\
\text { ronment-related criteria; fostering "eco-career"; employee } \\
\text { rewarding according to environment-related criteria }\end{array}$ & ScoreCard, Environment-related project (Very limited) & 1 \\
\hline Profitability & Share programs & Not mentioned & 0 \\
\hline $\begin{array}{l}\text { Employee participation and } \\
\text { social dialogue }\end{array}$ & Different types and forms of participation & $\begin{array}{l}\text { Cooperation with nongovernmental organisations } \\
\text { (Very limited) }\end{array}$ & 1 \\
\hline Employee development & $\begin{array}{l}\text { Job rotation; different training forms and methods; } \\
\text { the transfer of experience; focus on future skills and } \\
\text { employability }\end{array}$ & Training and Development, remote learning (Limited) & 2 \\
\hline External partnership & $\begin{array}{l}\text { Cooperation with education system; partnership with } \\
\text { all external stakeholders }\end{array}$ & $\begin{array}{l}\text { Cooperation with nongovernmental organisations } \\
\text { (Very Limited) }\end{array}$ & 1 \\
\hline Flexibility & Flexible working arrangements; job rotation & Flexible working hours (Very Limited) & 1 \\
\hline $\begin{array}{l}\text { Compliance beyond labour } \\
\text { regulations }\end{array}$ & $\begin{array}{l}\text { Involves employee representatives in many decision- } \\
\text { making processes beyond those for which worker } \\
\text { participation is a statutory requirement; financial and } \\
\text { nonfinancial support }\end{array}$ & $\% 40$ unionised employees (Very Limited) & 1 \\
\hline Employee cooperation & $\begin{array}{l}\text { Teamwork; good relationships of managers and } \\
\text { employees }\end{array}$ & Not mentioned & 0 \\
\hline Fairness and equality & $\begin{array}{l}\text { Fostering diversity; respectful relationships; fair remu- } \\
\text { neration, career }\end{array}$ & Equal opportunity principles (Very Limited) & 1 \\
\hline
\end{tabular}

Source: Authors' own description, based on research results. 
Among the seven banks, two of the top three highest scoring banks are public banks (Halkbank and Vakıfbank). This finding directly supports the shift in the public sector from a traditional bureaucratic model to the new management approach that transfers private sector management techniques to the public sector (Brown, 2004). For Turkey, it can be easily said that public banks are very successful in applying new management techniques in order to survive amid high competition and due to strong corporate governance regulations. Also, it should be noted that the finance sector is a leading sector in Turkey, and these two banks are open to the public at a level of nearly 25 percent. Subsequently, no significant difference was found between the people-oriented score and process-oriented score of public banks (17 to 12, 14 to 11), which can be expressed as "balanced," compared to private banks (except Şekerbank). Thus, private banks can be expressed as strongly people-oriented due to significant differences such as " 23 to 13 " or " 15 to 5. ."

Moreover, horizontal scoring is done to determine the total score achieved by each sustainable HR characteristic from all the banks. Table 7 shows the scores achieved by each sustainable HR characteristic.

Table 7. Scores Achieved by Banks from Each Characteristic

\begin{tabular}{lc}
\hline Characteristics of Sustainable HRM & SCORES \\
\hline Long-term orientation & 17 \\
Care of employees & 18 \\
Care of environment & 5 \\
Profitability & 13 \\
Employee participation and social dialogue & 17 \\
Employee development & 20 \\
External partnership & 16 \\
Flexibility & 4 \\
Compliance beyond labour regulations & 16 \\
Employee cooperation & 16 \\
Fairness and equality & 18 \\
\hline
\end{tabular}

Source: Authors' own description, based on research results.

Results of this analysis revealed that banks are mainly concentrated on "employee development," "care of employees," and "fairness \& equality" characteristics, while "care of environment" and "flexibility" receive only limited mention. This type of horizontal scoring gave us the chance to determine to what extent each characteristic is internalised by the banks. Although most of the banks achieved higher scores from people-oriented characteristics, "employee development," which is a processoriented characteristic, achieved the highest score from the horizontal analysis, and this is another interesting finding. The reason for such an interesting finding may be that core activities of "employee development" are considered as the main HR activities relevant for all type of companies.

\section{CONCLUSIONS}

Social, economic, and environmental issues such as global warming, depletion of natural resources, increasing population, poverty, and human rights violations reveal how important the concept of sustainability is. Therefore, one of the most important agenda items of organisations is sustainability, which has become an integral part of their strategies and operations. For business organisations, it is compulsory to develop a new perspective that caters to the resource constraints at issue. The concept of sustainable human resource management in the field of business and management has recently become increasingly popular for this purpose.

Sustainable human resource management considers human rights, supports the freedom of unionisation and collective bargaining of employees, ends compulsory and child labour, and eliminates all kinds of discrimination in recruitment. The characteristics of sustainable HR such as long-term orientation, care of employees, care of environment, profitability, employee participation and social dialogue, employee development, external partnership, flexibility, compliance beyond labour regulations, employee cooperation, fairness and equality were used in this study.

Previous studies on sustainable HR are mainly conceptual, trying to highlight the importance of the relationship between sustainability and the HR vision of the companies. Ehnert et al. (2016) analysed the sustainability reports of Forbes' top 250 
global companies by using GRI indicators on labour statistics, labour performance, and human rights disclosures. They applied the "indexing technique," which is very common in sustainability reporting analyses, and concluded that further research is needed to shape the "sustainable HRM" concept. Our study mainly aimed to contribute to the "sustainable HRM" research area by using an in-depth content analysis combined with a "scoring technique." In addition, this study intended to provide an extended understanding of the relation between HR activities, HR involvement of the companies, and their outlook on sustainability. It is obvious that being more people-oriented will contribute directly to becoming a more sustainable organisation. The findings of our study offer a perspective on how to integrate HRM with sustainability and through which HR activities.

Future "sustainable HRM" research can concentrate on the sectoral differences in applying core characteristics of sustainable $\mathrm{HR}$ and comparisons of companies from different sectors with different company features. Finally, it is important to note that HRM is a very dynamic, fast-changing area, and sustainability reporting is evolving increasingly fast, which means that further research will have high potential to discover more about "sustainable HR" characteristics.

\section{REFERENCES}

Aggarwal, P., \& Singh, A. K. (2019). CSR and sustainability reporting practices in India: An in-depth content analysis of top-listed companies. Social Responsibility Journal, 15(8), 1033-1053.

Brown, K. (2004). Human resource management in the public sector. Public Management Review, 6(3), 303-309.

Chams, N., \& García-Blandón, J. (2019). On the importance of sustainable human resource management for the adoption of sustainable development goals. Resources, Conservation \& Recycling, 141, 109-122.

Cohen, E., Taylor, S., \& Muller-Camen, M. (2012). HRM's Role in corporate social and environmental sustainability SHRM Foundation. https://www. shrm.org/hr-today/trends-and-forecasting/special-reports-and-expert-views/Documents/Corporate-Social-Environmental-Sustainability.pdf

Daub, C. H. (2007). Assessing the quality of sustainability reporting: An alternative methodological approach. Journal of Cleaner Production, 15(1), 75-85.

De Stefano, F., Bagdadli, S., \& Camuffo, A. (2018). The HR role in corporate social responsibility and sustainability: A boundary-shifting literature review. Human Resource Management, 57(2), 549-566.

Ehnert, I. (2006, March 28-29). Sustainability issues in human resource management: Linkages, theoretical approaches, and outlines for an emerging field . 21st EIASM SHRM Workshop, Aston, Birmingham.

Ehnert, I. (2009). Sustainability and human resource management: Reasoning and applications on corporate websites. European Journal of International Management, 3(4), 419-438.

Ehnert, I. (2014). Paradox as a lens for theorizing sustainable HRM. (Eds. Ehnert I., Harry W., Zink K.), Sustainability and human resource management (pp. 247-271). Springer.

Ehnert, I., \& Harry, W. (2012). Recent developments and future prospects on sustainable human resource management: Introduction to the special issue. Management Revue, 23(3), 221-238.

Ehnert, I., Parsa, S., Roper, I., Wagner, M., \& Muller-Camen, M. (2016). Reporting on sustainability and HRM: A comparative study of sustainability reporting practices by the world's largest companies. The International Journal of Human Resource Management, 27(1), 88-108.

Freitas, W. R. S., Jabbour, C. J. C., \& Santos, F. C. A. (2011). Continuing the evolution: Towards sustainable HRM and sustainable organizations. Business Strategy Series, 12(5), 226-234.

Jabbour, C. J. C., \& Santos, F. C. A. (2008). The central role of human resource management in the search for sustainable organizations. The International Journal of Human Resource Management, 19(12), 2133-2154.

Jackson, S. E., Renwick, D. W. S., Jabbour, C. J. C., \& Muller-Camen, M. (2011). State-of-the-art and future directions for green Human Resource Management: Introduction into the special issue. German Journal of Human Resource Management: Zeitschrift für Personalforschung , 25(2), 99-116.

Kramar, R. (2014). Beyond strategic human resource management: Is sustainable human resource management the next approach? The International Journal of Human Resource Management, 25(8), 1069-1089.

Lam, H., \& Khare, A. (2010). HR's crucial role for successful CSR. Journal of International Business Ethics, 3, 3-15.

Macke, J., \& Genari, D. (2019). Systematic literature review on sustainable human resource management. Journal of Cleaner Production, $208,806-815$.

Malik, F., McKie, L., Beattie, R., \& Hogg, G. (2010). A toolkit to support human resource practice. Personnel Review, 39, $287-305$.

Mariappanadar, S. (2003). Sustainable human resource strategy: The sustainable and unsustainable dilemmas of retrenchment. International Journal of Social Economics, 30(8), 906-923.

Sneddon, C., Howarth, R. B., \& Norgaard, R. B. (2006). Sustainable development in a post-Brundtland world. Ecological Economics, 57(2), 253-268. Stankevičiūtè, Ž., \& Savanevičienè, A. (2018). Designing sustainable HRM: The core characteristics of emerging field. Sustainability, 10(12), 4798. 
Tooranloo, H. S., Azadi, M. H., \& Sayyahpoor, A. (2017). Analyzing factors affecting implementation success of sustainable human resource management (SHRM) using a hybrid approach of FAHP and type-2 fuzzy DEMATEL. Journal of Cleaner Production, 162, $1252-1265$.

Ulrich, D. (1997). Human resource champions: The next agenda for adding value and delivering results. Harvard Business School Press.

Vormedal, I., \& Ruud, A. (2009). Sustainability reporting in Norway-an assessment of performance in the context of legal demands and sociopolitical drivers. Business Strategy and the Environment, 18(4), 207-222.

Wagner, M. (2013). 'Green' human resource benefits: Do they matter as determinants of environmental management system implementation? Journal of Business Ethics, 114(3), 443-456.

Westerman, J. W., Rao, M. B., Vanka, S., \& Gupta, M. (2020). Sustainable human resource management and the triple bottom line: Multi-stakeholder strategies, concepts, and engagement. Human Resource Management Review, 30(3), 100742.

Wikhamn, W. (2019). Innovation, sustainable HRM and customer satisfaction. International Journal of Hospitality Management, 76, $102-110$.

World Commission on Environment and Development (WCED). (1987). Our common future: Report of the World Commission on Environment and Development. Oxford University Press.

Zink, K. J. (2014). Social sustainability and quality of working life. In I. Ehnert, W. Harry, \& K. J. Zink (Eds.), Sustainability and human resource management (pp. 35-56). Springer. 